\title{
Distal falanks kırıkları
}

\section{Fractures of the distal phalanx}

\author{
Mehmet Çolak, Metin Manouchehr Eskandari
}

Mersin Üniversitesi Tıp Fakültesi, Ortopedi ve Travmatoloji Anabilim Dalı, El Cerrahisi Bilim Dalı, Mersin

Elin distal falanks bölgesi, anatomik yerleşimi nedeniyle, sık yaralanır. Yaralanma mekanizması genellikle direkt travma olduğundan, eşlik eden yumuşak doku hasarı ciddi düzeydedir. İndirekt mekanizmayla oluşan kırıklar ise tanı güçlüğü taşıyabilir. Tedavi ve prognozu, yumuşak dokuların durumu ve uygun pozisyonda ve dozda çekilmiş direkt grafilerdeki bulgular belirler. İşlevsel geri kazanım elde etmek için kemiksel iyileşme sağlanmanın yanı sıra yumuşak dokuların, özellikle de tırnak komponentlerinin, uygun tedavi edilmesi şarttır. Sıklıkla acil servislerde ve polikliniklerde karşılanan ve müdahale edilen distal falanks travmalarının tedavisi, çoğunlukla suboptimal düzeyde kalmakta ve sonuç olarak tırnak deformiteleri, ağrılı kaynamama veya interfalangeal eklem sorunları ile sonlanmaktadır. Oysa ki, hasar tespitinin tam yapılması ve uygun tedavi ile tatminkar sonuçlar elde etmek mümkündür. Bu derleme yazıda distal falanks bölgesini ilgilendiren yumuşak doku yaralanmaları ve kırıklarının tedavi ilkeleri ele alınmıştır.

Anahtar sözcükler: parmakların falanksları, distal; tırnak yatağı; kopma kırı̆ı̆; kırıklar, Seymour
The distal phalangeal region of the hand is prone to injury because of its anatomical placement. Since the injury mechanism is commonly direct trauma, concomitant soft tissue injury is serious. When the mechanism is indirect trauma, diagnosis of the fractures may be difficult. Careful evaluation of the soft tissues and properly taken direct roentgenograms determine the management and prognosis. In order to regain function, the soft tissues, especially the nail components have to be treated properly in addition to treatment of the fracture. Distal phalanx traumas are generally evaluated and sub-optimally managed in emergency units and polyclinics; as a result, these are prone to nail deformities, painful nonunions and phalangeal joint deformities. Whereas, with proper determination of injury and management, it is possible to achieve satisfactory results. In this review, the treatment principles of soft tissue injuries and fractures of distal phalangeal region are discussed.

Key words: phalanges of fingers, distal; nail bed; avulsion fracture; fractures, Seymour
E lin distal falanksları, vücudun en fazla travmaya maruz kalan bölgesidir. Travmanın mekanizmasına bağlı olarak, distal falanksta kırık ve bunun yanı sıra farklı şekil ve düzeylerde yumuşak doku hasarları ortaya çıkmaktadır. Tedavide iyi fonksiyonel sonuç elde etmek için bölge anatomisinin kavranması, kemik ve yumuşak doku hasarının dikkatle değerlendirilmesi ve uygun tedavi seçimi şarttır.

\section{BÖLGESEL ANATOMi}

\section{Distal falanks ve distal interfalangeal eklem anatomisi}

Diğer tüm falankslar gibi, distal falanksların epifizi proksimaldedir ve 3 yaş civarında kemikleşmeye başlar.
Epifizin diyafiz ile füzyonu 18-19 yaşlarda tamamlanır. Distal falanks, eklem yüzü barındıran geniş proksimal bölüm, daha dar olan cisim ve distalde tekrar genişleme gösteren tuft bölümlerinden oluşur. Cisim bölgesinde dorsal yüzey içbükey, voler yüz daha düzdür. Fleksör tendon falanksın voler proksimal ve lateral çıkıntılarına yapışır. Ekstansör tendon dorsal proksimaldeki çıkıntılı bölgeye yapışır. Parmak pulpası, tuft bölgesine yapışan bağ dokusu ağı ile hareketsizleşen bölmelere ayrilır. ${ }^{[1]}$

Distal interfalangeal (DIP) menteşe tarzında bir eklemdir. Eklem kapsülü dorsalde genişleyen ekstansör tendon, her iki tarafta gerçek ve aksesuvaryan bağlarve volerde voler plak ile desteklenir. Tüm yan bağlar orta falanks başından başlarlar. Gerçek yan bağlar distal falanks voler yan tüberküllerine yapışırken, aksesuvar

- İletişim adresi: Prof. Dr. Metin Manouchehr Eskandari, Mersin Üniversitesi Tıp Fakültesi, Sağlık Araştırma ve Uygulama Merkezi, Zeytinlibahçe cad., Necdet Ülger binası 2. kat, Mersin. Tel: 0324 - 3374300 / 1155 e-posta: mmeskandari@yahoo.com

- Geliș tarihi: 25 Șubat 2014 Kabul tarihi: 25 Șubat 2014 
yan bağlar daha voler uzanımla voler plağa yapışırlar. Voler plağın dizginleyici bağ uzantıları proksimal interfalangeal (PIP) eklemdekinin aksine proksimalde kemiğe yapışmayıp A4 askısına karışarak sonlanırlar (Şekil 1). Bu yüzden DIP eklem, PIP'e göre daha fazla hiperekstansiyon yapabilir. Başparmak interfalangeal (IP) eklem diğer DIP eklemlere benzer. Farklı olarak eklem kapsülünün voler ortasında bireylerin \%73'ünde bir sesamoid kemik bulunur ve voler plağı daha kalındır. $\mathrm{Bu}$ özellik flexor pollisis longus (FPL) tendonun etkinliğini arttırır. Diğer parmakların DIP eklemleri $90^{\circ}$ fleksiyon ve $10^{\circ}$ ekstansiyona getirilebilirken, başparmak IP ekleminin fleksiyonu aynı, ekstansiyonu $25^{\circ}$ 'dir. ${ }^{[1-3]}$

\section{Tırnak bölgesi anatomisi}

Tırnak, distale doğru laminalar şeklinde oluşup uzayan keratinize yapıdır. Tırnağı çevreleyen komşu yumuşak doku bölgelerinin tamamına perionişyum denir. Perionişyum, tırnağın altında tırnak yatağı, tırnağın proksimalinde tırnak oluğu ve eponişyum, tırnağın her iki tarafında paronişyum ve tırnağın distal komşuluğunda hiponiş̧yumdan oluşmaktadır (Şekil 2). Tırnak yatağının dorsal yüzeyini, proksimalde germinal matriks ve distalde steril matriks örter. Germinal matriks, tırnak oluşturan hücrelerden oluşur. Tırnak proksimalinde yarım ay şeklinde beyaz bir bölge olarak görülür ve bu görünüm nedeniyle 'lunula' olarak da adlandırılır. Steril matriks daha fazla kapiller ağ içerdiği için dıştan pembe renkli görülür. Tırnak yatağı distal falanks dorsalinin periostuna yapışık ve hareketsizdir. Tırnak oluğu, tırnak kökünün yerleştiği ceptir. Eponişyum ve tırnak üzerindeki sonlanma kenarı olan kütikül, tırnak proksimalinde tırnak oluğunun dorsalini örten cilt bölgesidir. Kapiller ve lenfatik dolaşımdan son derece zengin olan ince yapıdaki eponişyum, mikroorganizmaların girişini engelleyici etkiye sahiptir. Paronişyum ve hiponişyum tırnağın her iki taraf ve distalindeki cilt bölgeleridir. ${ }^{[4,5]}$ Tırnağın ortalama büyüme hızı günde $0,1 \mathrm{~mm}$ 'dir. Tırnağın \%90'ını germinal matriks üretir. Steril matriks tırnağın alt yüzeyine ince bir hücresel tabaka ekleyerek, tırnak yatağına yapışık ve düzgün yüzeyli kalmasını sağlar. Germinal matriksi ilgilendiren hasarlar tırnak kaybı ile sonuçlanırken, steril matriks hasarları tırnakta deformite oluşumuna neden olurlar.

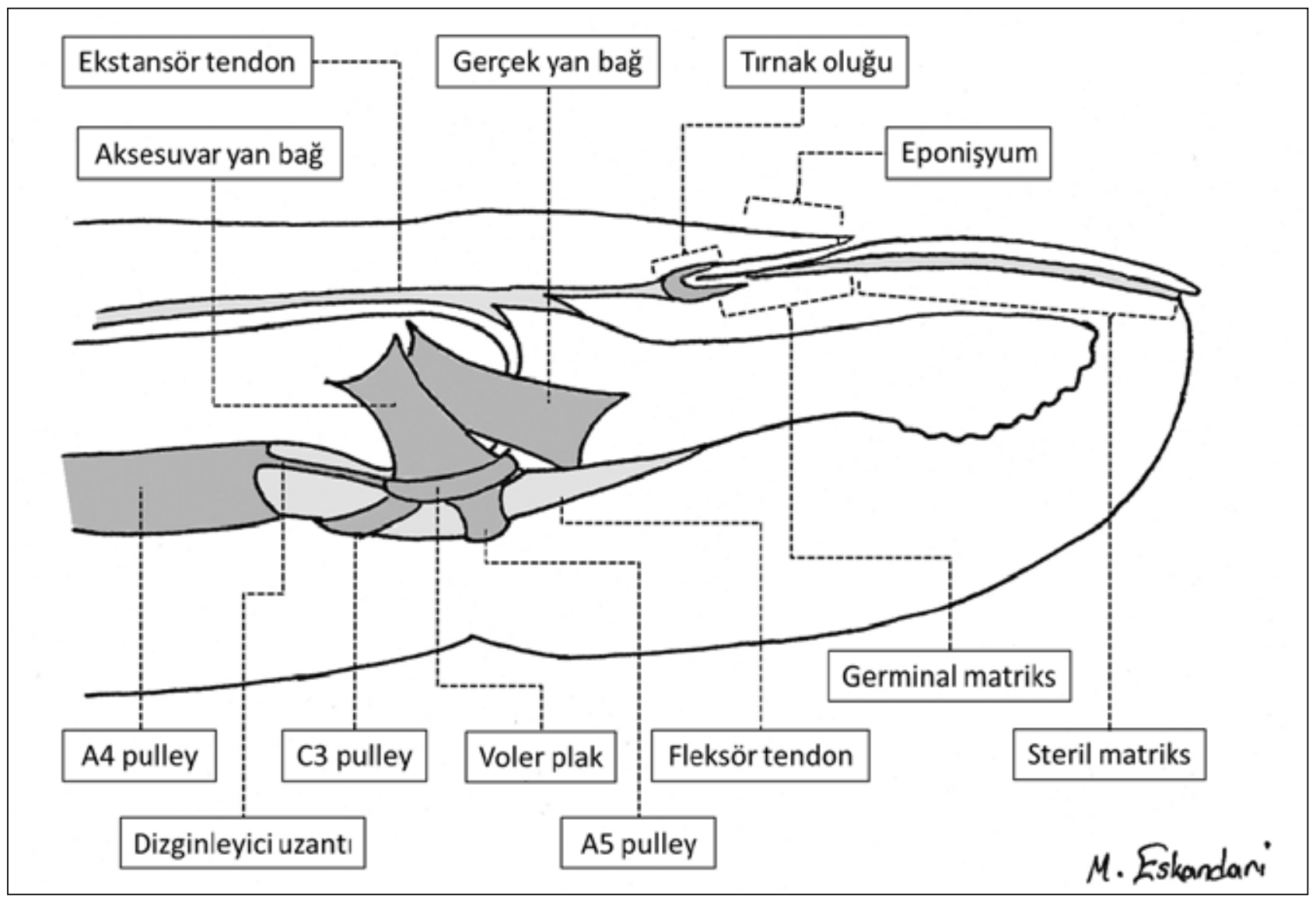

Şekil 1. Distal interfalangeal eklem ve distal falanks bölgesinin anatomisi. 
Perionişyumun beslenmesi dijital arterlerin uç dalları ve kapiller ağ ile sağlanır. Tırnak yatağı, venöz dönüşün ilk durağı olarak görev görür. Tırnak yatağının duyusu, hem volerden gelen ulnar ve radyal dijital sinirlerin dorsal dallanmaları, hem de radyal sinir kaynaklı dorsal dijital sinirler aracılığıyla taşınır. ${ }^{[4,6]}$

\section{TIRNAK YATAĞI YARALANMALARI}

Tırnak bölgesi hasar ve anormallikleri hem kozmetik hem de fonksiyonel kayba yol açar. Tırnağın başlıca fonksiyonları; kaşıma, çizme, parmak ucunu koruma, pulpaya stabilite kazandırarak tutma gücünü arttırma, vücut ısı düzenlenmesine katkı, çok küçük objelerin tutulmasını sağlama ve parmak pulpasının dokunma duyusunu desteklemektir. Öyküde yaralanma mekanizmasının sorgulanması, hasarın düzeyi ve genişliği hakkında önemli ipuçları vermektedir. Kapı sıkışması, ağır cisimler ile ezici darbeler ve iş aletleri ile delinme ve yaralanma, sırasıyla en sık mekanizmalardır. Yaralanma en çok çocuk ve gençlerde ve diğer parmaklardan daha uzun olması nedeniyle orta parmakta görülür..$^{[4,8]}$

\section{Tırnak altı hematomu}

Tırnak altı hematomu, kapalı yaralanma olması ve tırnak yatağının hasar düzeyinin görülememesi nedeniyle tedavisi en tartışmalı yaralanmadır. Hemen her zaman ezici darbelerle tırnak yatağının yaralanması sonucunda oluşur. Tırnak sağlam kaldığında hematom boşalamaz ve bulunduğu sınırlı bölgede basınç artışı ile zonklayıcı ağrı yapar. Geçmişte tırnağın kaldırılması ve yatağının onarılması için kabul gören temel endikasyon, hematomun tırnak genişliğinin \%50'sinden fazlasını tutmuş olması idi..9,10] Ancak daha yeni çalışmalar, boyutundan bağımsız olarak, hematomun boşaltılması ile tırnak deformitesi gelişmediğini göstermektedir. ${ }^{[11-14]} \mathrm{Bu}$ yaklaşıma göre tırnak ve kenarları kesik, hasarlı ve ayrılmış ise tırnak yatağı onarımı ve bunun için tırnağın kaldırılması endikedir. Eğer hematom varlığı dışında tırnak ve çevresinin bütünlüğü korunduysa, sadece hematomun boşaltılması yeterlidir. ${ }^{[12-14]}$ Tırnağın delinme işlemi için matkap ucu, iğne ya da pilli mikrokoter ucu kullanılabilir. Tırnak, yatağına zarar vermeden ve devamlı boşalmaya izin verecek yeterli genişlikte delinmelidir. ${ }^{[4]}$

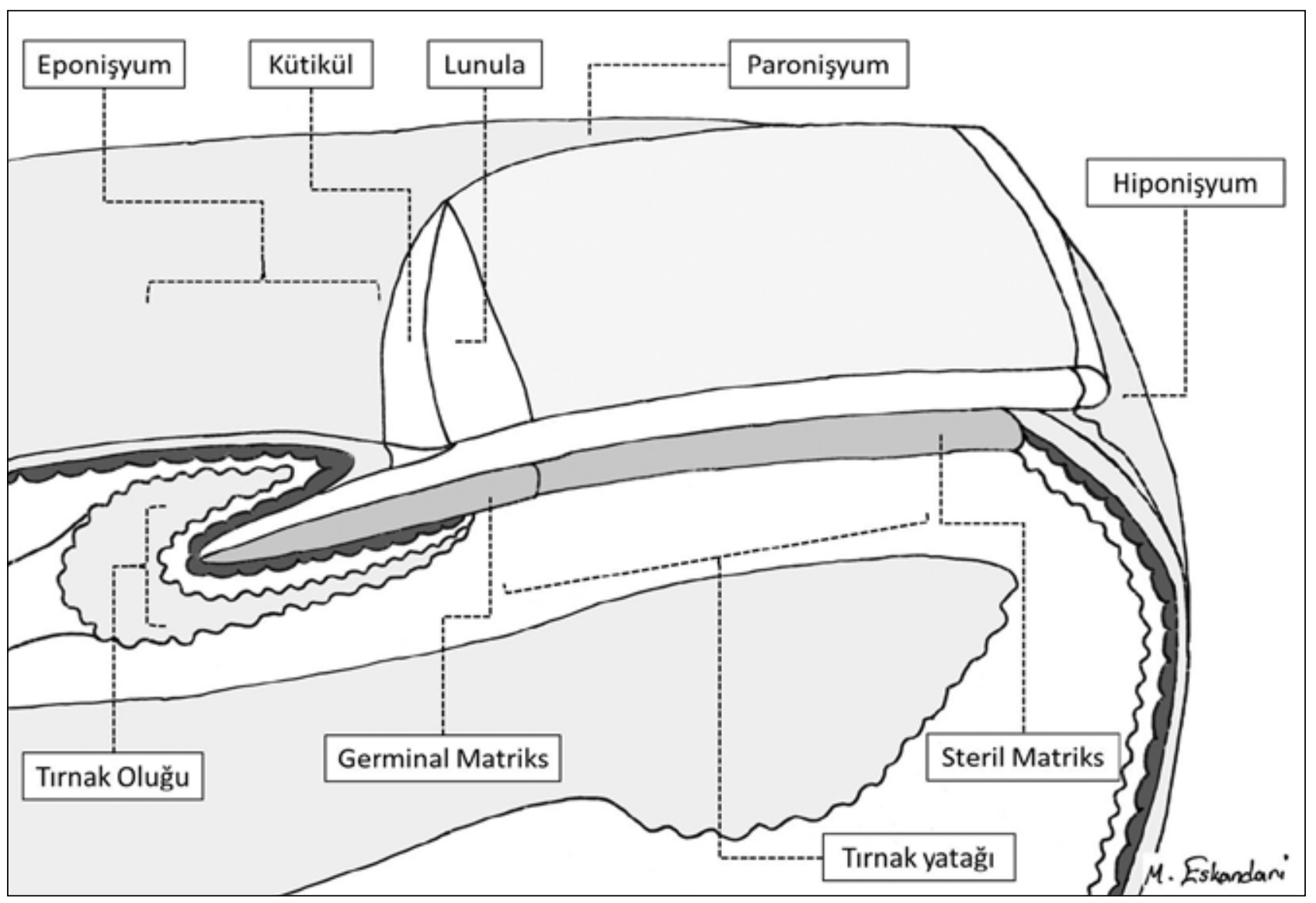

Şekil 2. Tırnak ve tırnak çevresi (perionişyum) anatomisi. 

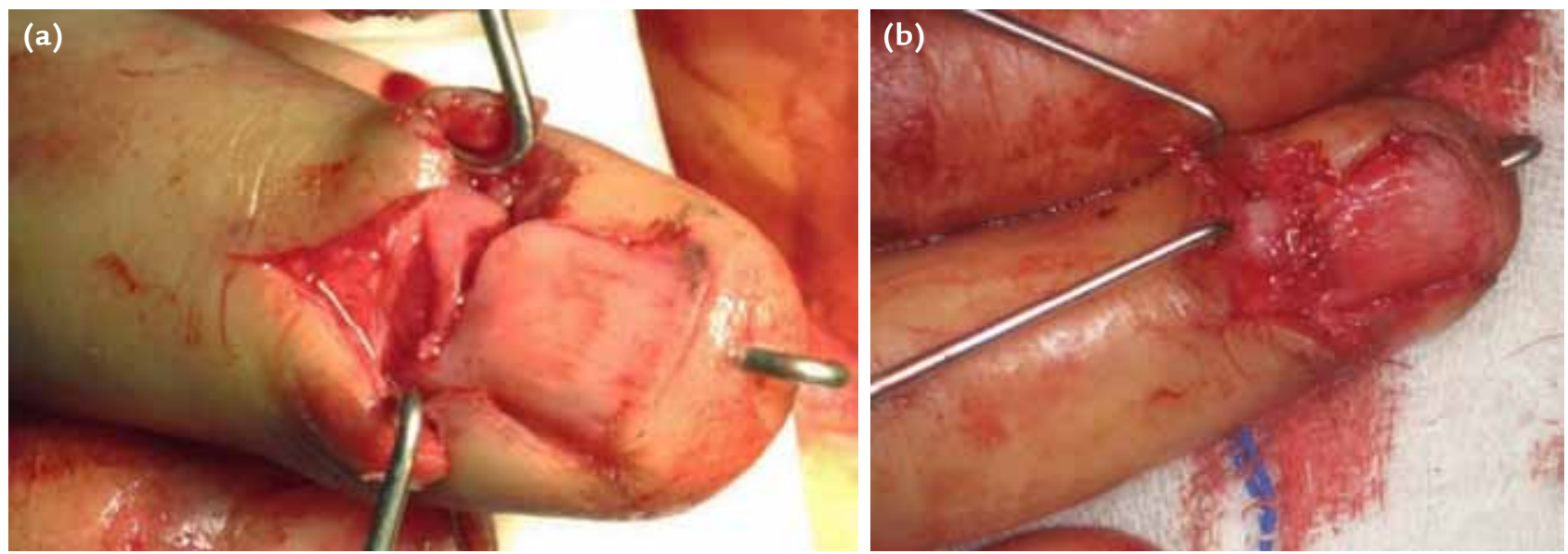

Şekil 3. a, b. Tırnak yatağı yaralanması (a) olan olgumuzun mikroskop altında 7-0 sütür materyali ile tamir edildikten sonraki görünümü (b).

Tırnak yatağının onarımı özel çaba gerektiren bir süreçtir. Bu işlem lokal anesteziyi tolere edebilen yaşta olan bireylerde dijital blok ve parmak turnikesi altında yapılır. Tırnak, yatağından kaldırılırken yatağına zarar vermemek için nazik davranmalıdır. Tırnak kaldırıldıktan sonra alt yüzeyi temizlenmeli ve yatak onarımı yapılırken antiseptik solüsyonda bekletilmelidir. Tırnak yatağı, büyütme aracı kullanarak değerlendirilmeli ve kesinin kenarları düzensiz ise minimal debridman yapılmalıdır. Tırnak yatağının kesi kenarlarını birer milimetreye kadar kemikten sıyırıp serbestleştirmek, kesinin kapatılmasını kolaylaştırabilir. Daha fazla sıyırma önerilmemektedir. Tırnak yatağı onarımında 7-0 spatula uçlu iğneli krome dikiş materyali kullanılır. Düğüm sayısının az olması için devamlı sütür tekniği kullanılır (Şekil 3). Tırnak yatağının tamirinden sonra tırnak yatağı kalıba alınmalı, korunmalı ve tırnağın doğurgan matriksi ile tırnak oluğu arasında yapışıklık oluşumu engellenmelidir. Bu amaçlar için en uygun koruyucu ve interpozisyon materyali tırnağın kendisidir. Tırnak geri konabilecek nitelikte ise hematom oluşumunu engellemek için delinir ve yerine konduktan sonra 5-0 naylon ile hiponişyum ya da tırnak oluğuna dikilerek tespit edilir. Tırnağın kayıp ya da kullanılamayacak şekilde hasarlı olduğu durumlarda, hazır satılan özel yapay tırnak protezi, tırnak şekli verilmiş ince silikon tabaka, serum setinin esnek polipropilen haznesinden şekillendirilmiş bir parça ya da bunlar temin edilemezse tek kat yapışmayan gazlı bez parçası kullanılabilir. Pansumandan sonra onarımın desteklenmesi ve ağrının azalması için 2-3 hafta süreyle volerden atelleme önerilmektedir. ${ }^{[4,15]}$

\section{Tırnak yatağının kopma yaralanması}

Genellikle tırnakyerinden ve proksimaldeki oluğundan çıkmıştır ve tırnak yatağının büyük bir bölümü tırnağa yapışık olarak distal falankstan ayrışmıştır. Sıklıkla en distalde tırnak ve parmak ucunun bağlantısı devam etmektedir. Bu durum çocukta görülürse Salter-Harris Tip I epifiz yaralanmasının işareti olarak kabul edilmeli ve yan plan başta olmak üzere direkt grafi çekilmelidir. Cerrahide tam görüş ve tamirin sağlanabilmesi için kütikül dönüş yerlerine $90^{\circ}$ açıyla cilt kesileri yapılır (Şekil 4) ve eponişyum kaldırılarak tırnak ve yatağı yerine konur ve eponişyum 6-0 nylon ile dikilir. Tam kopma ve ayrışma durumunda da, tırnağa yapışık olan tırnak yatağı greft olarak kullanılarak yerine dikilir. ${ }^{[4,15,16]}$

\section{Tırnak yatağında defekt oluşturan yaralanmalar}

$\mathrm{Bu}$ yaralanmalarda deformite (onikoliz, distrofi, ptergium, yarık tırnak vb.) oluşmasından kaçınmak için defektin onarımı şarttır. Küçük defektler çevre yatağın serbestleştirilmesi ile primer kapatılabilirler. Bu işlemin koşulları, serbestleştirilmesi gereken bölgenin, total tırnak yatağı genişliğinin 1/3'ünden az olması, defekt çevresinde yatağın sağlıklı olması ve serbestleştirme ile

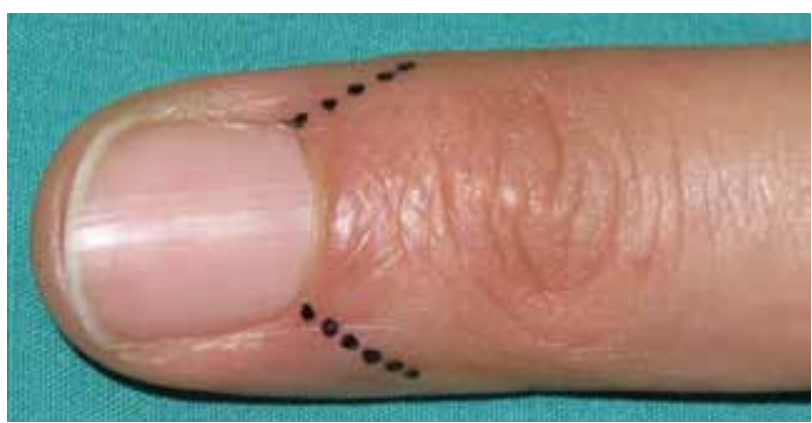

Şekil 4. Gerektiğinde eponişyumda tercih edilen kesi yerleri ve açıları. 
ilerletme işleminin atravmatik yapılabilmesidir. ${ }^{[17-19]}$ Defekt alanı tırnak yatağının \%50'sinden küçük ise aynı parmak sağlam bölge tırnak yatağından tam kat olmayan greft alınarak onarım yapılabilir. Defekt bölgesi yatağın \%50'sinden büyük ise, hastanın seçimine göre, ayak parmağı ya da komşu parmaktan greft alınabilir. Greft, sadece steril matriks bölgesinden alınmalı, germinal matrikse uzanmamalıdır. Distal falanks, çıplak kemik korteksi üzerine konan greftin yaşayabildiği nadir vücut bölgelerindendir. ${ }^{[4,15,16,20]}$

\section{DISTAL FALANKS KIRIKLARI}

\section{Kapalı kırıklar}

Distal falanks kırıkları, tuft, cisim ve eklem içi olmak üzere üçe ayrılır. Bu kırıklar en fazla baş ve orta parmaklarda görülür. ${ }^{[21]}$

\section{Tuft kırıkları}

Sıklıkla ezilme mekanizması ile oluşur ve pulpa ile tırnak matriks yaralanması eşlik eder. Basit, az yer değiştirmiş kırıklarda ağrıya yönelik, tırnak altı hematomun boşaltılması ve iki haftalık immobilizasyon tedavide yeterli olur. Hematom boşaltılması için tırnak delindiyse kırık artık açık kabul edilir ve kısa dönem antibiyotik profilaksisi gereklidir. Bu kırıklar sıklıkla içten tespit gerektirmez. Dıştan tespitin de PIP eklemini kapsamaması ve en çok üç hafta sürdürülmesi tavsiye edilir. Kırığın parçalı oluşu, önemli düzeyde pulpa ve tırnak matriks hasarının göstergesidir. Bu tip kırıklarda tırnak yatağının yaklaştırılarak dikilmesi gerekebilir. Amaç kırık parçalarını yaklaştırmak ve ağrılı skar dokusu ile tırnak deformitesi oluşumunu azaltmaktır. Bu işlemler de kapalı kırığı açık hale getirir. ${ }^{[21-23]}$

\section{Cisim kırıkları}

Distal falanks cisim kırıkları transvers veya longitudinal uzanımlı olabilir. Transvers kırıklar yer değiştirmemişse stabildir ve içten tespit gerektirmez; yer değiştirdiyse bir K-teli ya da mini vida ile tespit edilir. Yer değiştirmiş kırklar hemen her zaman açık ve tırnak yatağındaki yırtılma ile birliktedir. Bu yaralanmaların tedavisi açık kırıklar bölümünde ayrıntılı olarak ele alınacaktır. Başparmak distal falanks transvers kırığı FPL yapışma yerinin distalindeyse, apeksi volerde açılanma yapar. Bu kırığın redüksiyonu dıştan atelleme ile sürdürülemiyorsa IP eklemi geçen tek perkütan K-teli ile tespit edilir. Başparmak distal falanks logitudinal kırığı nadirdir ve deplase ise yandan gönderilen K-teli ile tespit edilir (Şekil 5). ${ }^{[21]}$

Distal falanks cisim kırıklarında semptom oluşturan kaynamama ve yanlış kaynama nadirdir. Semptomatik kaynamama için K-teli ile tespit ve greftleme etkili bulunmuştur. ${ }^{[24,25]}$ Yapısal bir greftin veya kanüllü kompresyon vidasının kapalı yöntemle distalden proksimale doğru yerleştirilmesi diğer seçeneklerdir. ${ }^{[26,27]}$

\section{Eklem içi kırıklar ve çocukların epifizer kırıkları}

Distal interfalangeal eklemi ilgilendiren distal falanks kırıkları, ekstansör ve fleksör tendon kopma kırıkları ile çocuklarda görülen epifizer kırıklar olmak üzere, iki ana kategoride görülür. Kopma yaralanmaları bu yazının sonraki bölümlerinde ayrıca ele alınacaktır. Epifiz kırıkları adolesanda Salter-Harris Tip III iken daha küçük çocuklarda Tip I veya II'dir. Bu yaralanmalar aşırı fleksiyona zorlanma mekanizması ile oluşur. Direkt radiyografideki değerlendirme zorluğu tendon kopması veya DIP çıkığı tanısına yol açabilir. ${ }^{[28]}$ Proksimal epifizer fragmana ekstansör tendon, kırık distaline flexor digitorum profundus
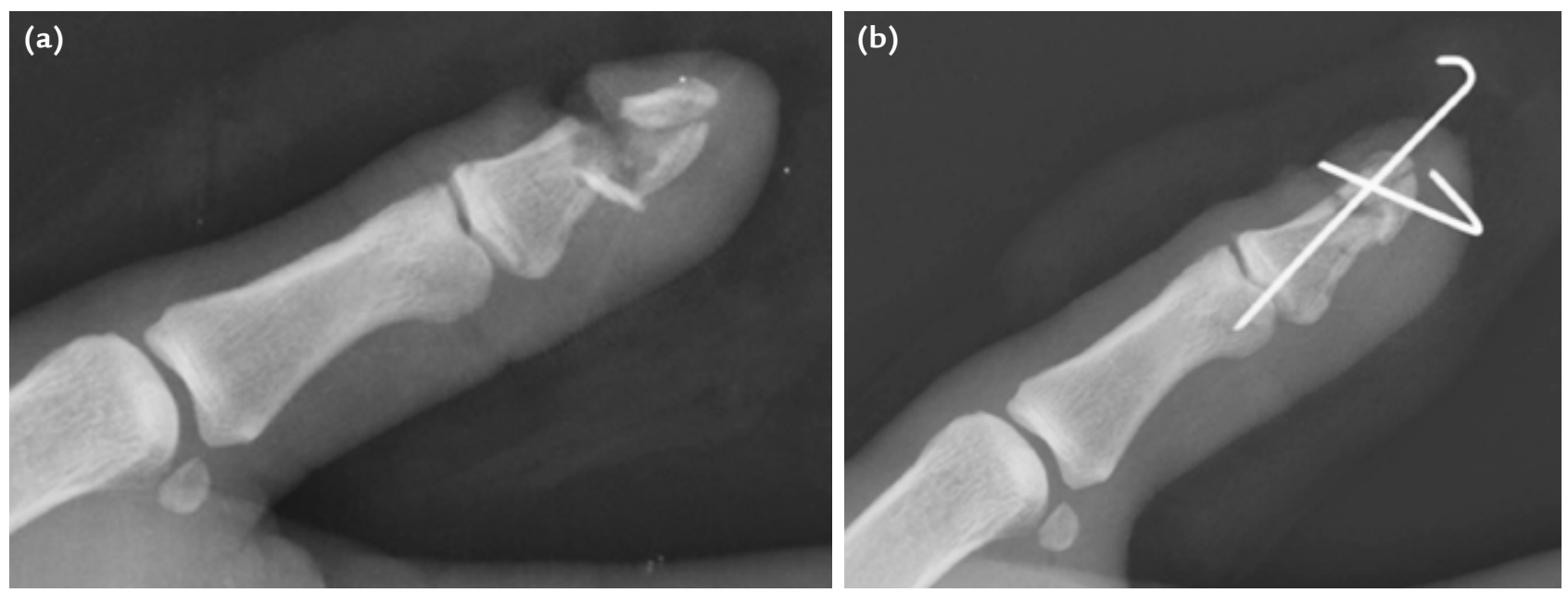

Şekil 5. a, b. Başparmak distal falanksta hem longitudinal hem de transvers kırı̆̆ı olan olgumuzun ameliyat öncesi (a), ve tırnak yatağı tamiri artı çift K-teli ile tespit yapıldıktan sonraki (b) grafileri. 
(FDP) yapıştığından kırık hattı fleksiyona gelir. Üç yaş altındaki çocuklarda distal falanks epifizinde kemikleşme bulunmadığından Tip I yaralanmanın radyolojik tanısı mümkün değildir. Distal falanks epifizi tamamen dorsale yer değiştirmiş olabilir. Bu durumda tanı konamayan ve yetersiz tedavi edilen parmağın dorsalinde giderek büyüyen kemik çıkıntısı oluşur. Geç de olsa tedavi açık redüksiyondur, ancak bir aydan sonra DIP eklemin tam fleksiyonu kazanılamayabilir. ${ }^{[29]}$

\section{Erişkinde açık, tırnak yatağı yaralanması ile birlikte olan kırıklar}

Açık tırnak yatağı yaralanmasına sıklıkla distal falanks kırığı eşlik eder. ${ }^{[30,31]} \mathrm{Bu}$ olgularda tedavinin amacı ağrısız kaynama ve düzgün dorsal korteks ile tırnak yatağı yüzeyi elde etmektir. Tırnağın korunabildiği, yer değiştirmemiş kırıklarda, tırnak yatağının tamirinden sonra tırnağın yerine konması kırık tespiti için de yeterlidir. Tırnak yaralanması ile birlikte olup daha fazla stabilite gerektiren ayrılmış distal falanks kırıklarının cerrahi tespiti için düşey 8 şeklinde gergi bandı tekniği kullanılabilir (Şekil 6a). Gergi bandı sütürü, pulpa yeterince stabil olduğunda, 3-6 hafta sonra alınmaktadır. Pulpada ciddi ezilme veya onarılmış doku kaybı varsa ya da volarde cilt bütünlüğü bozuksa, gergi bandının distal tutulumu falanksa yerleştirilen bir tel etrafından sağlanabilir (Şekil $6 b)$. Bu tekniklerin başarısında, tırnak yerleşimi ve tırnak yatağının düzgünlüğünün sağlanması önemlidir. Tırnağın kayıp olduğu durumlarda ve yer değiştirmiş ya da tırnak oluğunun proksimalinde olan kırıklarda, K-teli ile içten tespit endikedir. Rotasyonel stabilite elde etmek için birden fazla K-teli yerleştirilmesi önerilir. Bu teller paralel ya da çapraz gönderilebilir. Kalın olmayan (0,7-0,8 mm'lik) teller kullanımına ve mümkünse DIP eklemin geçilmemesine dikkat edilir. ${ }^{[32,34]}$

\section{Seymour kırıkları}

Çocukların distal falanks epifizine yakın kırıklarına, hemen her zaman tırnak yatağında transvers hatı kesi ve tırnak proksimalinin cilt dışına çıkması eşlik eder. Bunlara 'Seymour kırıkları' denir. Tedavide yıkama ve debridman sonrası tırnak yatağı tamir edilir ve tırnak yerine konulur. Tırnak proksimalindeki cildin kova sapı yaralanması redüksiyona engel olabilir. Tırnağın korunarak tırnak oluğuna yerleştirilmesi, kırığı da destekleyerek tespit eder. Kırıkta stabilite elde edilirse distal fragmanı ekstansiyonda tutan atel yapılır. Stabilitede kuşku varsa DIP eklemi ve kırığı tespit eden K-teli yerleştirilir. Bu kırıklar fizis hattına çok yakın olsa da, iyi redüksiyon ve etkin splintleme sayesinde, genellikle büyüme problemlerine yol açmaz. Yetersiz debridman ve yıkama durumunda gelişebilecek infeksiyon, büyüme kusuruna neden olabilir. Bu yüzden ameliyat sonrası beş gün antibiyoterapi önerilmektedir. ${ }^{[21,35,36]}$ Erişkinlerde distal falanksın hiperfleksiyonu sonucunda ekstansör tendonun 1-2 mm distalinde oluşan transvers metafizer kırıklar çekiç parmak yaralanmasını taklit eder. Bu yaralanmalar 'Seymour tipi kırıklar' olarak adlandırılır. Kapalı yaralanmalar, redüksiyonu takiben stabilite durumuna göre splint veya perkütan K-teli ile tedavi edilebilir. Açık yaralanmalar ise açık redüksiyon, tırnak yatağı onarımı ve K-teliyle tespit edilerek tedavi edilir. ${ }^{[37]}$

\section{PARMAKLARIN DIP VE BAŞPARMAĞIN IP ÇIKIKLARI}

Parmakların DIP ve başparmağın IP çıkıkları genellikle dorsal yönde ve üzerindeki ince cilt örtüleri nedeniyle açık yara ile birliktedir. Bu eklemlerde PIP ekleme göre çıkık oluşumu daha azdır. Nedeni, daha kısa etki kolu bulundurmaları ve üzerlerinde sonlanan
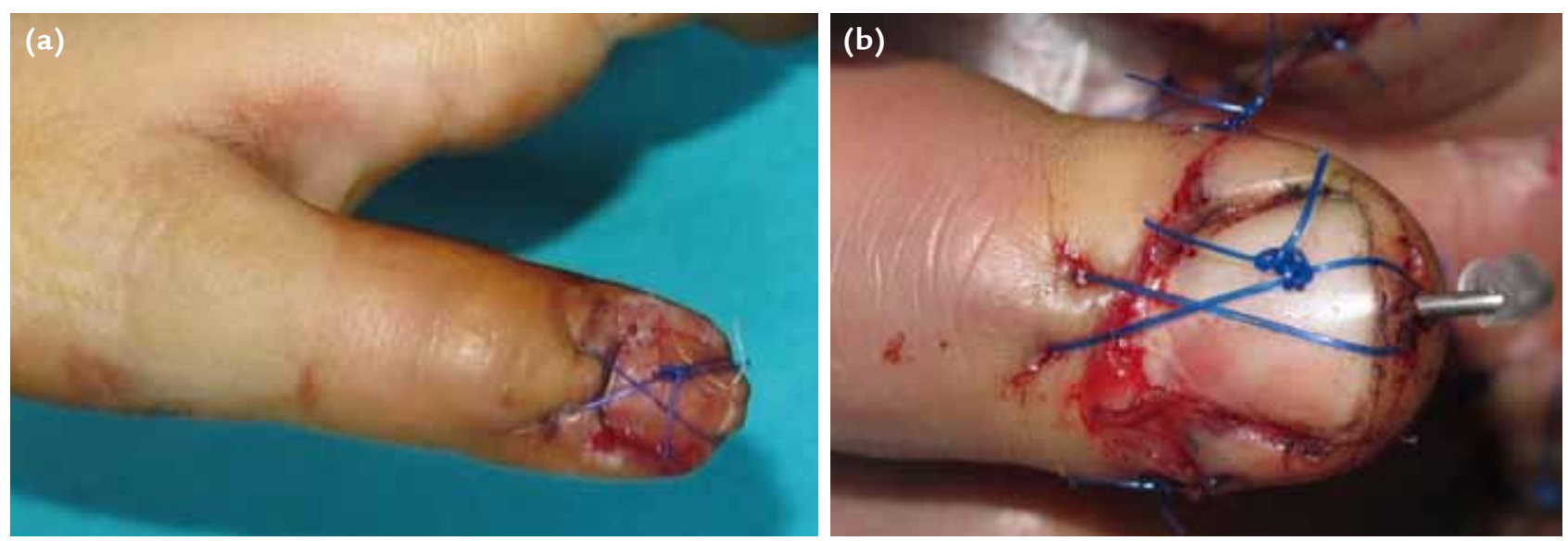

Şekil 6. a, b. Tırnak yaralanmasına eşlik eden ayrılmış distal falanks kırıkları olan olgularımızda 8 şeklinde gergi bandı vertikal sütür teknikleri: K-teli kullanılmadığında (a) ve K-teli varlığında (b). 
fleksör ile ekstansör tendonların stabilizatör etkileridir. Redüksiyon dijital veya el bileği blok anestezisi altında yapılır. Açık yara varsa uygun steril koşullarda yaranın yıkanması ve debridmanı yapılır. Redüksiyon için traksiyon ile birlikte distal falanks dorsaline baskı yapılır ve distal falanks fleksiyona getirilir. Redüksiyon yapıldıktan sonra stabilite mutlaka test edilmelidir. Kırık eşlik etmeyenlerde redüksiyon hemen her zaman stabildir. Bu durumda eklemi hafif fleksiyonda tespit eden dorsal atel uygulanır. Birinci haftadan sonra atel, son $20^{\circ}$ 'lik ekstansiyonu önleyecek ve aktif eklem fleksiyonuna izin verecek şekilde modifiye edilir. ${ }^{[38]}$ Nadir de olsa DIP ve başparmak IP eklem çıkıkları kapalı olarak redükte edilemeyebilir. Bunun en sık nedeni yırtılmış voler plağın eklem arasına girmesidir. Diğer olası nedenler, fleksör tendon, kırık parçası ya da sesamoid kemiğin araya girmesi olabilir. Direkt grafide eklem aralığı interpoze doku nedeniyle belirgin olarak genişlemiştir. Bu durumda açık redüksiyon ile engelleyici yapı eklem aralığından uzaklaştırılmalıdır. ${ }^{[38,39]}$

Başparmak IP ve diğer parmakların DIP eklemlerin dorsal çıkıklarına nadir de olsa distal falanks voler dudak kırı̆ğ eşlik edebilir. Fleksör tendon bu parçayı yerinden ayırmadıysa, çıkığın kapalı redüksiyon sonrası cerrahi dışı tedaviye devam edilir. Parça ile birlikte fleksör tendon kopmuşsa, kırık eklem yüzeyinin \%40'ından fazlasını ilgilendiriyorsa ya da eklemin redükte kalabilmesi için fazla fleksiyon açısında tespit gerekiyorsa cerrahi tedavi endikedir. Cerrahi tedavide kırık tespiti ve fleksör tendon tamiri yapılır. Bu işlemlerin mümkün olmadığı parçalı kırıklarda voler plak artroplastisi yapılmalıdır. ${ }^{[38,40]}$ Distal interfalangeal eklemlerin kırıksız voler çıkıkları nadirdir. Bunlar temelde spontan redükte olmuş çekiç parmak yaralanmalarıdır. Tedavileri çekiç parmaktaki gibi en az altı hafta ekstansiyonda atellenmedir. ${ }^{[34]}$ Bu konuda daha ayrıntılı bilgi yazının sonraki bölümünde yer almaktadır.

\section{DISTAL FALANKS TENDON KOPMALARI ve KOPMA KIRIKLARI}

\section{Çekiç parmak yaralanması}

Çekiç parmak yaralanmalarının iki çeşidi tendinöz ve kemiksel kopmalardır. Çekiç parmak oluşumunun klinik bulgusu DIP ekleminde aktif ekstansiyon kaybıdır. Yaralanma tedavi edilmez ve kronikleşirse giderek DIP pasif ekstansiyonu da kaybedilir ve kompansatuvar kuğu boynu deformitesi nedeniyle PIP eklemde hiperekstansiyon postürü oluşur. ${ }^{[41]}$

Cerrahi dışı yöntemler çekiç parmak yaralanmalarının tedavisinde önemli yer tutmaktadır. Bu amaç için DIP eklemini ekstansiyonda tutan ateller kullanılır. Hiperekstansiyon, dorsal cilt hasarına yol açabileceği için tercih edilmemektedir. Etkinliği ve hastanın rahatlığına göre plastik, alüminyum ya da kişiye özgü termoplastik ateller dorsalden veya volarden uygulanabilir (Şekil 7). Ateldeyken eklemin uygun pozisyonda olduğunu kontrol etmek için parmak yan grafi çekilmesi
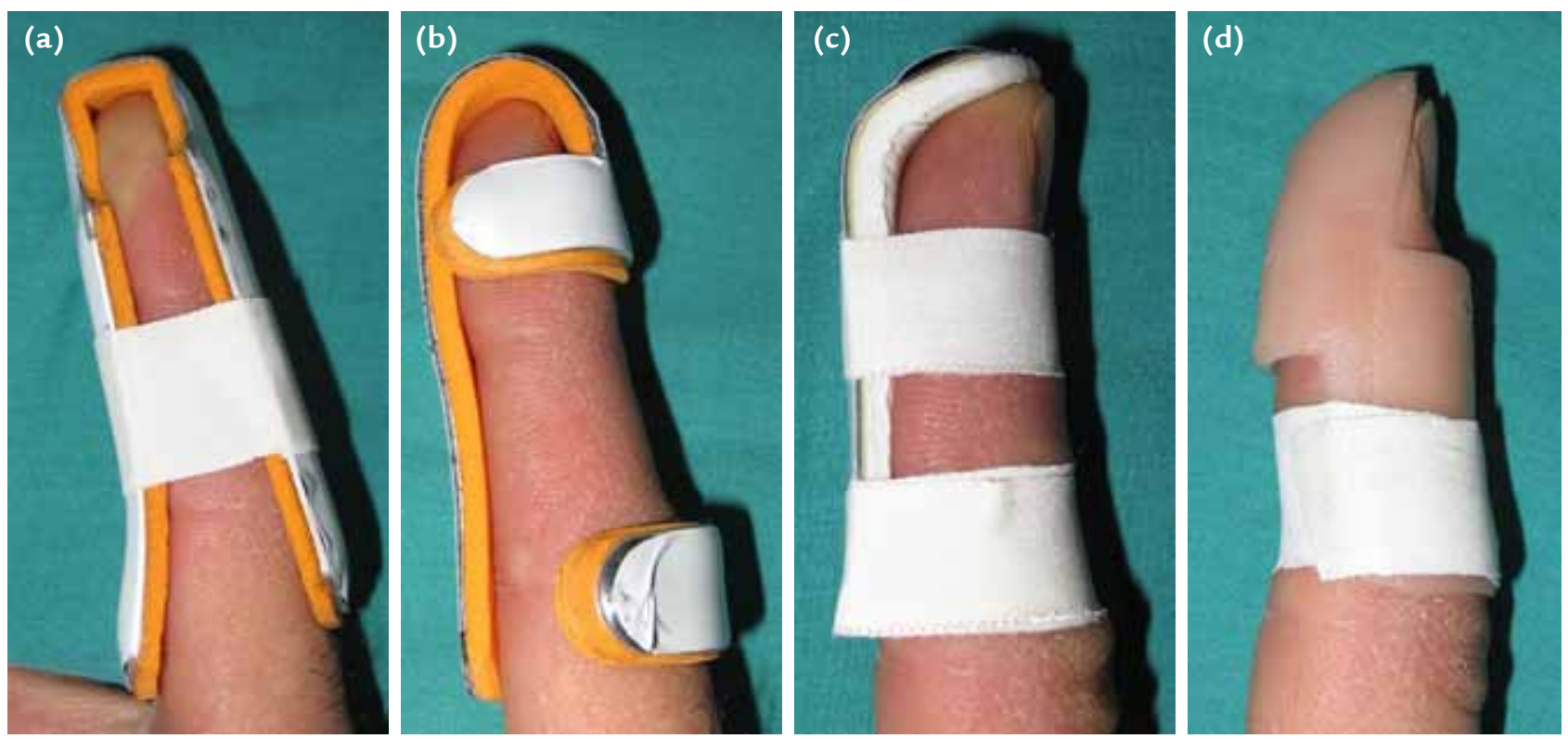

Şekil 7. a-d. Çekiç parmak yaralanmasında cerrahi dışı ya da ameliyat sonrası dönemde hastanın seçimi ve rahatlığına göre farklı tip ateller kullanılabilir. Temel amaç DIP eklem fleksiyonunu engellemektir. Alüminyum temelli ateller (a-c) ve en yaygın kullanılan plastik yapıdaki çekiç parmak ateli (d) örnek gösterilebilir. 
önerilir. Atelleme tedavisi, altı hafta süreyle sürekli, sonrasında altı hafta daha sadece gece ya da zorlu aktiviteler esnasında uygulanır. Sürekli atel uygulamasına hijyen bakımı amacıyla ara verildiğinde DIP eklemin tam ekstansiyonda desteklenmesi önemlidir. Bunu sağlayacak kadar koopere olmayan hastalarda DIP eklemini uygun pozisyonda tutan kalıcı sirküler alçı yapılabilir. Bu durumda üçüncü hafta sonunda alçı değişimi önerilir. Bu yöntemlerle $10^{\circ}$ veya daha az ekstansiyon gevşekliğinin kalması durumunda tedavinin başarılı olduğu kabul edilir. Bu kriter temelinde, atelleme ile tedavi başarı oranı \%80'in üzerinde bildirilmektedir. Çekiç başparmak kırığında, eklemde voler subluksasyon yoksa, hemen her zaman cerrahi dışı tedavi yapılır. Bu amaç için IP eklem 6-8 hafta ekstansiyonda atellenir. ${ }^{[21,41-43]}$

Çekiç parmak yaralanmalarının cerrahi tedavi endikasyonları tartışma konusudur. Yaygın kanı olarak kesin cerrahi endikasyon kabul edilen durumlar, açı yaralanma, atel ile çalışma olanağı olmayan bireyler, kopan dorsal parçanın büyük olup eklem yüzeyinin \%30'undan fazlasını içermesi ve DIP'te palmar subluksasyonun bulunmasıdır (Şekil 8). ${ }^{[41]}$ Diğer yandan çekiç parmak kırı̆̆ı ile birlikte distal falanksın palmar subluksasyonu bulunan olguların tedavisinde dahi farklı ve hatta zıt görüşler devam etmektedir. Parça boyutu eklem yüzünün 1/3'ünden büyük olduğu kapalı çekiç parmak yaralanmalarının
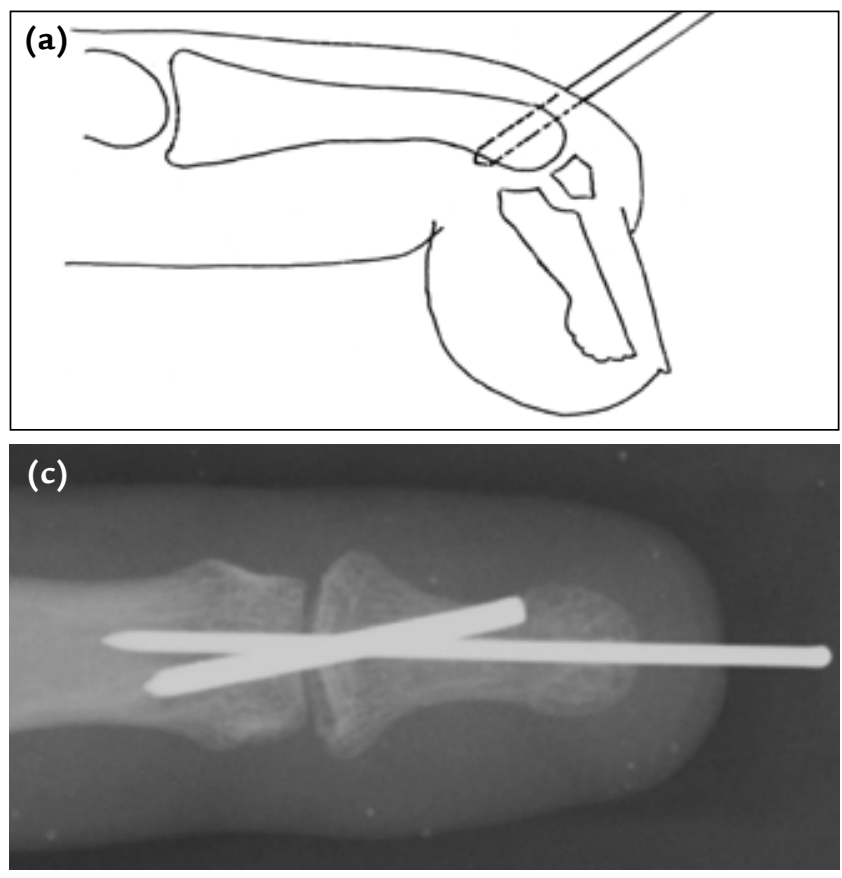

Şekil 9. a-d. Çekiç parmak kırığında ekstansiyon blok teli yöntemi. DIP eklem fleksiyona getirilir ve floroskopi altında $45^{\circ}$ açıyla proksimal falanks distaline K-teli gönderilir (a), parmak ekstansiyona getirilince kırık parçası redükte olur ve bu pozisyonda gönderilen ikinci K-teli ile eklem tespit edilir (b). Bu yöntem ile tedavi edilmiş olgumuzun ameliyat sonrası arka-ön (c) ve yan grafileri (d).

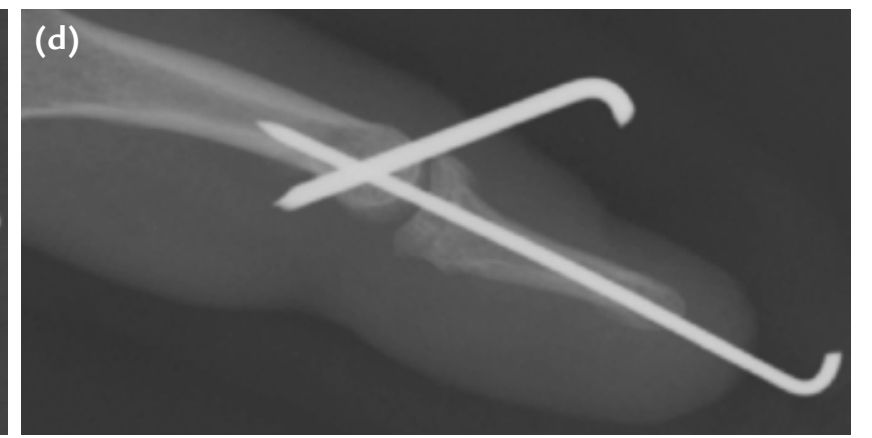

geriye dönük incelemesinde voler subluksasyon olan grupta terminal ekstansiyon eksikliği, ağrılı dorsal kemik çıkıntısı ve artrit gibi bulgular daha fazla gözükse de cerrahi dışı tedaviyle genelde tatminkar sonuçlar bildirilmiştir. ${ }^{[44]}$ Wehbe ve Schneider ${ }^{[45]}$ diğer tüm çekiç parmak yaralanmalarındaki gibi palmar subluksasyonu olan olguların da cerrahi dışı atelleme ile tedavi edilmelerini önermektedirler. Doyle ${ }^{[46]}$ ise dorsal parçanın ciltten çıkarmalı (pull out) dikiş ile yerine getirilmesi ve DIP eklemin K-teli ile tespit edilmesini önermektedir. Çekiç parmak kırıklarının kapalı redüksiyonu ve tespiti için günümüzde belki de en çok uygulanan teknik, ekstansiyon blok teli ve modifikasyonlarıdır (Şekil 9). ${ }^{[47-51]}$

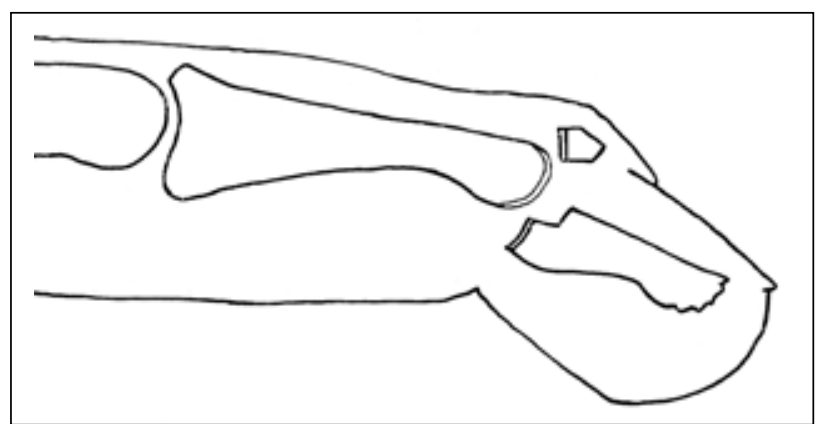

Şekil 8. Çekiç parmakkırığında temel radyografikcerrahi endikasyonlar olan kopan parçanın eklem yüzeyinin \%30'undan fazlasını içermesi ve eklemde voler subluksasyonunun şematik görünümü.

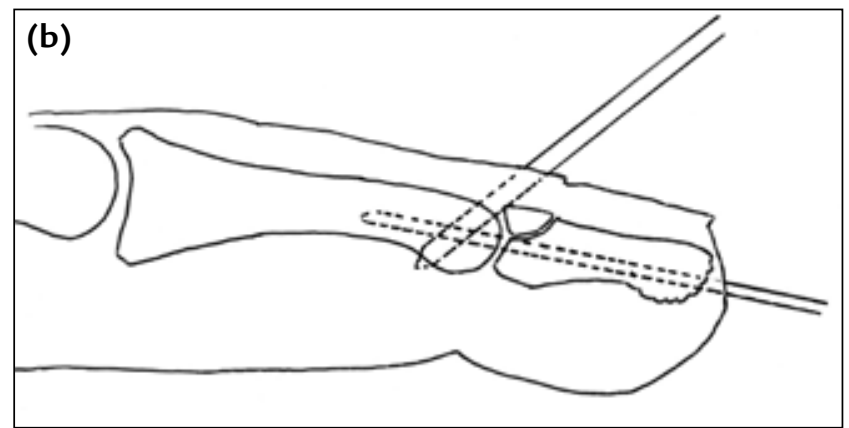


Son zamanlarda tercih edilen diğer bir teknik de kancalı plak kullanımıdır. Dengesiz eklem içi kırıklarda kancalı plak ile yapılan tespit, erken dönemde aktif parmak hareketine izin verecek kadar denge sağlamaktadır. ${ }^{[52]}$ Sınırlı deneyimimize göre bu teknikte dikkat edilecek en önemli husus, dorsal cildin nekrozunu engellemek için cerrahi girişim esnasında cilt ve ekstansör tendon kılıfının birlikte kaldırılmasıdır (Şekil 10).

\section{Fleksör tendon kopma yaralanması}

Bu yaralanmalar parmakların fleksör tendonlarının indirekt mekanizma ile distal falankstan kopmasıdır ve
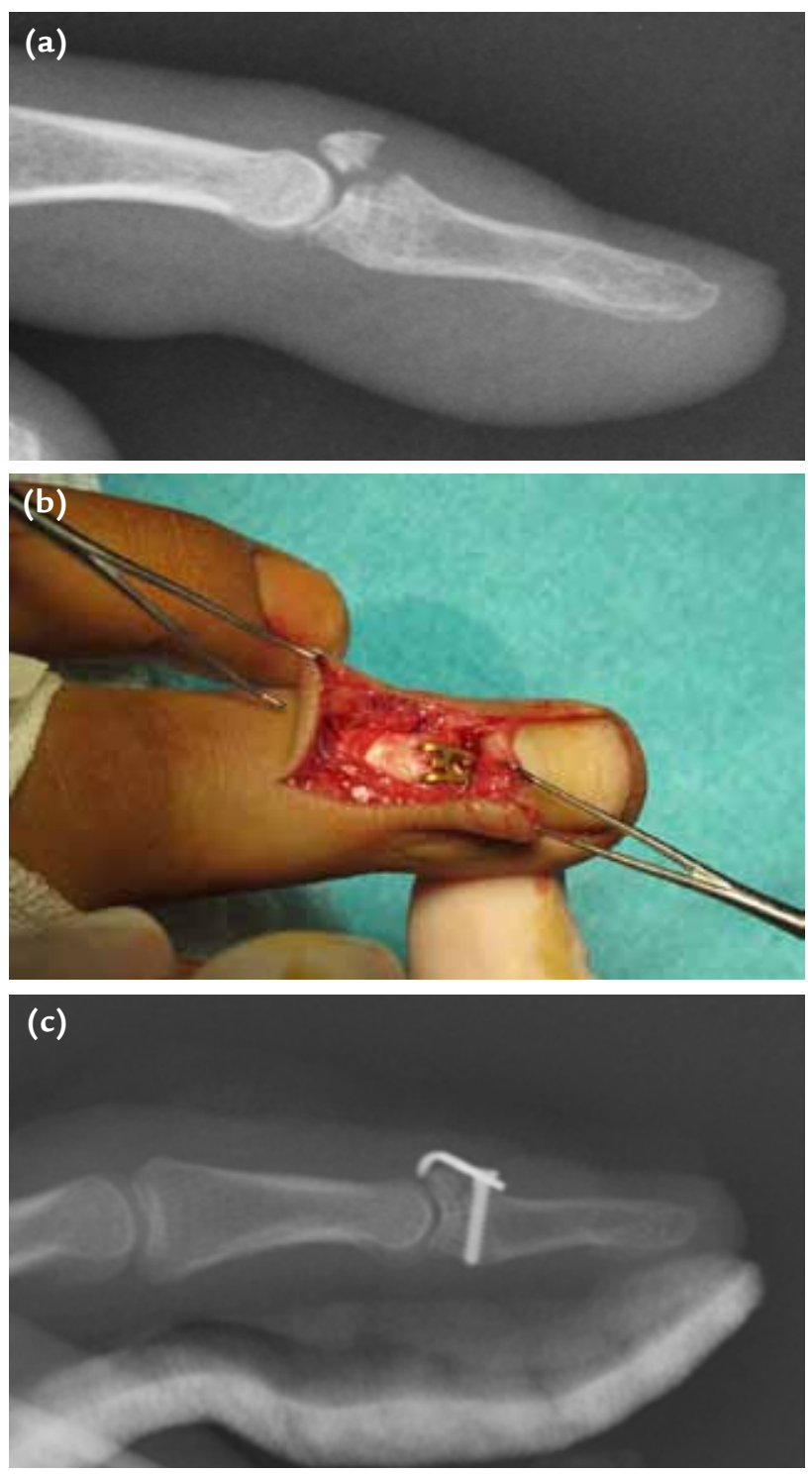

Şekil 10. a-c. Çekiç parmak kırığında kancalı plak uygulaması. On yedi yaş erkek hastada ameliyat öncesi yan grafi (a), plak yerleştirildikten sonra ameliyat sırasında görünüm (b) ve ameliyat sonrası yan grafi (c). eklemin aktif fleksiyon kaybına yol açar. Bu olgularda fleksör tendonun kopan distal ucunda küçük bir kemik parçası bulunabilir. Bu parçayı görmek ve tendon ucunun nereye kadar geri çekildiğini belirlemek için iyi kalitede direkt grafiler gereklidir. Kemiksiz tendon ucunun lokalize edilmesinde manyetik rezonans (MR) ve ultrasonografi (US) yardımcı olabilir. Başparmakta FPL'nin kopma kırığı nadirdir ve sıklıkla impaksiyon mekanizması sonucu ve dorsal çıkık ile birlikte oluşur. ${ }^{[21,53]}$

Fleksör tendon kopmaları dört tipe ayrılır. Tip I'de vinküler sistem yırtılmıştır ve tendonun ucu avuç içine çekilmiştir. Bu tipte tendon kılıfı da hasarlıdır ve birkaç günde tendon geçişine izin vermez durumuna gelebilir. Bu tipte tedavinin başarılı olması, ilk üç haftada tanı ve tedavinin gerçekleşmesine bağlıdır. Tip II'de vinküler sistem ve kılıf büyük ölçüde hasarsızdır. Tendon ucu PIP seviyesine kadar geri çekilmiştir. Tip III'te tendon güdügünde büyükçe bir kemik parçası vardır. Bu parça genellikle $A 4$ pulley'in distaline takılı kalır ve proksimale çekilmeyi engeller. Klasik sınıflamaya yeni eklenen ve Tip IV olarak kabul edilende kopmuş kemik parçası vardır ve tendon bu parçadan ayrışmıştır. Bu tipte $A 4$ pulley'in distaline takılı olan parçaya sıklıkla sadece DIP voler plağının bir kısmı yapışır. Tendonun ucu kılıf içinde ya da avuca kadar geri çekilmiştir. ${ }^{[33-55]} \mathrm{Al}-\mathrm{Q} a t \operatorname{ttan}^{[56]}$ kemik parçasıyla birlikte avülse olmuş fleksör tendon yaralanmasına ek olarak distal falanks kırı̆ıı olan hastaları ayrı sınıflamaktadır (Tip V).

Fleksör tendon kopma yaralanmalarının tedavisi cerrahidir. Geri çekilmiş tendon ucu distale getirilip distal falanksa tamir edilir. Tendon-kemik tespiti için farklı yöntemler kullanılabilir. Bunların arasında tendon güdügüünü kavrayan çoklu bant dikişlerin falankstan geçirilerek tırnak üzerinde düğme ile tespiti, kemiği geçen sütürün cilt altında düğümlenmesi ve kemikte kancalı dikiş kullanımı sayılabilir. İki bantlı tendon sütürleri yetersiz kalabilir. Çok gergin yapılan dikişler kuadriga etkisine yol açabilir. Sütürler distal falanksta açılan deliklerden tırnak dorsaline geçirilecekse, bu deliklerin germinal matriks (lunula) distalinde kalmasına dikkat edilmelidir. Aksi durumda eponişiyal hasar ya da tırnak deformitesi oluşumu söz konusu olabilir. Tırnaktan geçirilerek dorsal düğme ile tespit edilen sütür, ameliyat sonrası altıncı haftada hafifçe çekilerek tırnağa sıfır olarak kesilir. Büyük kemik parça ile birlikte olan kopmaların (Tip III) tedavisinde kemik parçasının açık redüksiyonu ve K-teli (Şekil 11) ya da vida (Şekil 12) ile tespiti yapılır. Tamir, travma sonrası altıncı haftaya kadar mümkündür. Tip IV yaralanmalarda öncelikle kemik parçasının tespiti yapılır. Daha sonra tendonun ucu distale çekilir ve distal falanksa dikilir. Onuncu günden sonraki gecikmeler kemik parçasının tespitini zorlaştırabilir, bu durumda parça eksizyonu ve tendonun kemiğe gecikmiş birincil onarımı yapılır. ${ }^{[43,53]}$ 

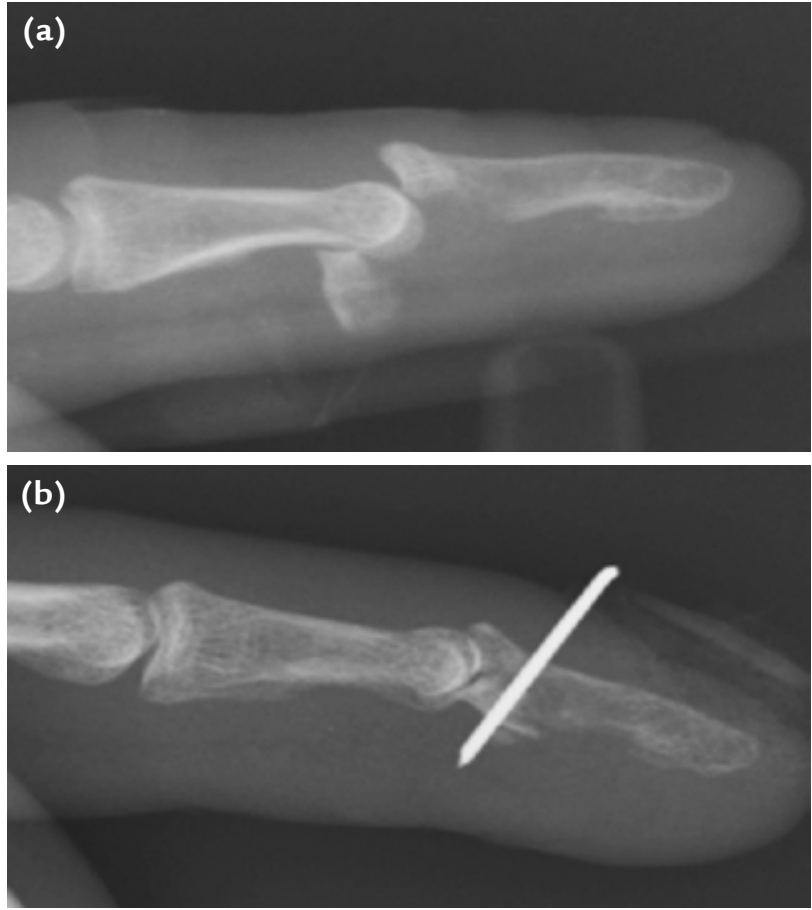

Şekil 11. a, b. Fleksör tendon avulsiyon kırığı olan olgumuzun ameliyat öncesi (a), K-teli ile fragman tespiti artı tırnaktan çıkarmalı dikiş ile tedavisi sonrası (b) yan grafileri. Ameliyat sonrası grafide tırnak dorsalinde görülen materyal serum setinden hazırlanan dikiş düğmesidir.

\section{KAYNAKLAR}

1. Schmidt HM, Lanz U. Palmar aspect of finger. In: Schmidt HM, Lanz U, editors. Surgical Anatomy of the Hand. Stutgart/New York: Thieme; 2004. p.173-212.

2. Schmidt HM, Lanz U. Thumb. In: Schmidt HM, Lanz U, editors. Surgical Anatomy of the Hand. Stutgart/New York: Thieme; 2004. p.85-113.

3. Shin AY, Amadio PC. Stiff finger joints. In: Green DP, Hotchkiss RN, Pederson WC, Wolfe SW, et al., editors. Green's Operative Hand Surgery. 5th ed. Philadelphia: Elsevier; 2005. p.417-38.

4. Sommer NZ, Richard E. Brown RE. The Perionychium. In: Green DP, Hotchkiss RN, Pederson WC, Wolfe SW, et al., editors. Green's Operative Hand Surgery. 5th ed. Philadelphia: Elsevier; 2005. p.389-416.

5. de Berker D. Nail anatomy. Clin Dermatol 2013;31(5):50915. CrossRef

6. Schmidt HM, Lanz U. Dorsal aspect of finger. In: Schmidt HM, Lanz U, editors. Surgical Anatomy of the Hand. Stutgart/New York: Thieme; 2004. p.241-52.

7. Zook EG. Anatomy and physiology of the perionychium. Hand Clin 2002;18(4):553-9.

8. Pearce $S$, Colville RJ. Nailbed repair and patient satisfaction in children. Ann R Coll Surg Engl 2010;92(6):483-5. CrossRef

9. Wei FC, Epstein MD, Chen HC, Chuang CC, Chen HT. Microsurgical reconstruction of distal digits following mutilating hand injuries: results in 121 patients. Br J Plast Surg 1993;46(3):181-6.
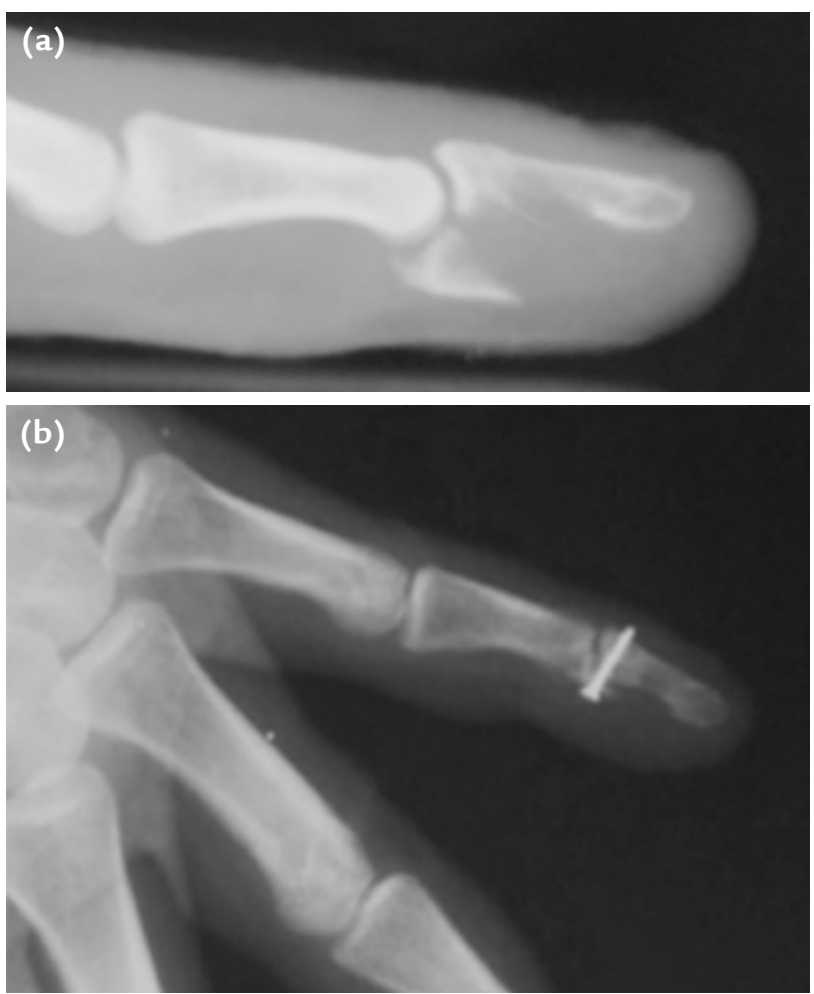

Şekil 12. a, b. Fleksör tendon avulsiyon kırı̆̆ı olan olgumuzun ameliyat öncesi (a), ve bir adet mini vida ile tespit yapıldıktan sonraki (b) yan grafileri.

10. Zook EG, Van Beek AL, Russell RC, Beatty ME. Anatomy and physiology of the perionychium: a review of the literature and anatomic study. J Hand Surg Am 1980;5(6):528-36.

11. Seaberg DC, Angelos WJ, Paris PM. Treatment of subungual hematomas with nail trephination: a prospective study. Am J Emerg Med 1991;9(3):209-10.

12. Roser SE, Gellman H. Comparison of nail bed repair versus nail trephination for subungual hematomas in children. J Hand Surg Am 1999;24(6):1166-70.

13. Gellman H. Fingertip-nail bed injuries in children: current concepts and controversies of treatment. J Craniofac Surg 2009;20(4):1033-5. CrossRef

14. Dean B, Becker G, Little C. The management of the acute traumatic subungual haematoma: a systematic review. Hand Surg 2012;17(1):151-4.

15. Tos $P$, Titolo $P$, Chirila NL, Catalano F, Artiaco S. Surgical treatment of acute fingernail injuries. J Orthop Traumatol 2012;13(2):57-62. CrossRef

16. Dumontier C. Distal replantation, nail bed, and nail problems in musicians. Hand Clin 2003;19(2):259-72.

17. Antony AK, Anagnos DP. Matrix-periosteal flaps for reconstruction of nail deformity. Plast Reconst Surg 2002;109(5):1663-6.

18. Johnson RK. Nailplasty. Plast Reconstr Surg 1971;47(3):275-6.

19. JellinekNJ. Flapsin nail surgery. DermatolTher 2012;25(6):53544. CrossRef

20. Haneke E. Nail surgery. Clin Dermatol 2013;31(5):516-25. CrossRef 
21. Stern PJ. Fractures of the metacarpals and phalanges. In: Green DP, Hotchkiss RN, Pederson WC, Wolfe SW, et al., editors. Green's Operative Hand Surgery. 5th ed. Philadelphia: Elsevier; 2005. p.277-341.

22. Al-Qattan MM, Hashem F, Helmi A. Irreducible tuft fractures of the distal phalanx. J Hand Surg Br 2003;28(1):18-20.

23. Oetgen ME, Dodds SD. Non-operative treatment of common finger injuries. Curr Rev Musculoskelet Med 2008;1(2):97102. CrossRef

24. Itoh $Y$, Uchinishi K, Oka Y. Treatment of pseudoarthrosis of the distal phalanx with the palmar midline approach. J Hand Surg Am 1983;8(1):80-4.

25. Ozçelik IB, Kabakas F, Mersa B, Purisa H, Sezer I, Ertürer E. Treatment of nonunions of the distal phalanx with olecranon bone graft. J Hand Surg Eur Vol 2009;34(5):638-42. CrossRef

26. Henry M. Variable pitch headless compression screw treatment of distal phalangeal nonunions. Tech Hand Up Extrem Surg 2010;14(4):230-3. CrossRef

27. Shinomiya $R$, Sunagawa $T$, Ochi $M$. Bone peg fixation for the treatment of nonunion of the shaft of the distal phalanx. J Hand Surg Eur Vol 2010;35(9):769-71. CrossRef

28. Ganayem M, Edelson G. Base of distal phalanx fracture in children: a mallet finger mimic. J Pediatr Orthop 2005;25(4):487-9.

29. Vadivelu R, Dias JJ, Burke FD, Stanton J. Hand injuries in children: a prospective study. J Pediatr Orthop 2006;26(1):29-35.

30. Weichman KE, Wilson SC, Samra F, Reavey P, Sharma S, Haddock NT. Treatment and outcomes of fingertip injuries at a large metropolitan public hospital. Plast Reconstr Surg 2013;131(1):107-12. CrossRef

31. Zook EG. Reconstruction of a functional and aesthetic nail. Hand Clin 2002;18(4):577-94.

32. Memon FW. Results of vertical figure-of-eight tension band suture for finger nail disruptions with fractures of distal phalanx. Indian J Orthop 2012;46(3):346-50. CrossRef

33. Bindra RR. Management of nail-bed fracture-lacerations using a tension-band suture. J Hand Surg Am 1996;21(6):1111-3.

34. Patankar HS. Use of modified tension band sutures for fingernail disruptions. J Hand Surg Eur Vol 2007;32(6):668-74.

35. Al-Qattan MM. Extra-articular transverse fractures of the base of the distal phalanx (Seymour's fracture) in children and adults. J Hand Surg Br 2001;26(3):201-6.

36. Krusche-Mandl I, Köttstorfer J, Thalhammer G, Aldrian S, Erhart J, Platzer P. Seymour fractures: retrospective analysis and therapeutic considerations. J Hand Surg Am 2013;38(2):258-64. CrossRef

37. Ugurlar M, Saka G, Saglam N, Milcan A, Kurtulmus T, Akpinar F. Distal phalanx fracture in adults: Seymour-type fracture. J Hand Surg Eur Vol 2014;39(3):237-41.

38. Steven Z. Glickel, O. Alton Barron, Louis W. Catalano III. Dislocations and Ligament Injuries in the Digits. In: Green DP, Hotchkiss RN, Pederson WC, Wolfe SW, et al., editors. Green's Operative Hand Surgery. 5th ed. Philadelphia: Elsevier; 2005. p.342-88.
39. Abouzahr MK, Poblete JV. Irreducible dorsal dislocation of the distal interphalangeal joint: case report and literature review. J Trauma 1997;42(4):743-5.

40. Rettig ME, Dassa G, Raskin KB. Volar plate arthroplasty of the distal interphalangeal joint. J Hand Surg Am 2001;26(5):940-4.

41. Baratz ME, Schmidt CC, Hughes TB. Extensor Tendon Injuries. In: Green DP, Hotchkiss RN, Pederson WC, Wolfe SW, et al., editors. Green's Operative Hand Surgery. 5th ed. Philadelphia: Elsevier; 2005. p.187-217.

42. Tocco S, Boccolari P, Landi A, Leonelli C, Mercanti C, Pogliacomi F, Sartini S, Zingarello L, Nedelec B. Effectiveness of cast immobilization in comparison to the gold-standard self-removal orthotic intervention for closed mallet fingers: a randomized clinical trial. J Hand Ther 2013;26(3):191-200. CrossRef

43. Tuttle HG, Olvey SP, Stern PJ. Tendon avulsion injuries of the distal phalanx. Clin Orthop Relat Res 2006;445:157-68.

44. Kalainov DM, Hoepfner PE, Hartigan BJ, Carroll C 4th, Genuario J. Nonsurgical treatment of closed mallet finger fractures. J Hand Surg Am 2005;30(3):580-6.

45. Wehbé MA, Schneider LH. Mallet fractures. J Bone Joint Surg Am 1984;66(5):658-69.

46. Doyle JR. Extensor tendons-acute injuries. In: Green DP, editor. Operative Hand Surgery. 3rd ed. New York: Churchill Livingstone; 1993:1950-98.

47. Ishiguro $\mathrm{T}$, Itoh $\mathrm{Y}$, Yabe $\mathrm{Y}$, Hashizume $\mathrm{N}$. Extension block with Kirschner wire for fracture dislocation of the distal interphalangeal joint. Tech Hand Up Extrem Surg 1997;1(2):95-102.

48. Mazurek MT, Hofmeister EP, Shin AY, Bishop AT. Extensionblock pinning for treatment of displaced mallet fractures. Am J Orthop (Belle Mead NJ) 2002;31(11):652-4.

49. Pegoli L, Toh S, Arai K, Fukuda A, Nishikawa S, Vallejo IG. The Ishiguro extension block technique for the treatment of mallet finger fracture: indications and clinical results. J Hand Surg Br 2003;28(1):15-7.

50. Tetik C, Gudemez E. Modification of the extension block Kirschner wire technique for mallet fractures. Clin Orthop Relat Res 2002;(404):284-90.

51. Chung DW, Lee JH. Anatomic reduction of mallet fractures using extension block and additional intrafocal pinning techniques. Clin Orthop Surg 2012;4(1):72-6. CrossRef

52. Kang GC, Yam A, Phoon ES, Lee JY, Teoh LC. The hook plate technique for fixation of phalangeal avulsion fractures. J Bone Joint Surg Am 2012;94(11): e72. CrossRef

53. Boyer MI. Flexor Tendon Injury (Acute Injuries) In: Green DP, Hotchkiss RN, Pederson WC, Wolfe SW, et al., editors. Green's Operative Hand Surgery. 5th ed. Philadelphia: Elsevier; 2005. p.219-40.

54. Leddy JP. Avulsions of the flexor digitorum profundus. Hand Clin 1985;1(1):77-83.

55. Ruchelsman DE, Christoforou D, Wasserman B, Lee SK, Rettig ME. Avulsion injuries of the flexor digitorum profundus tendon. J Am Acad Orthop Surg 2011;19(3):152-62.

56. Al-Qattan MM. Type 5 avulsion of the insertion of the flexor digitorum profundus tendon. J Hand Surg $\mathrm{Br}$ 2001;26(5):427-31. 